Supplements

\title{
Regulation of nitrous oxide production in low oxygen waters off the coast of Peru
}

5 Claudia Frey ${ }^{1,2,{ }^{*}, \text { Hermann W. Bange }}{ }^{2}$, Eric P. Achterberg ${ }^{3}$, Amal Jayakumar ${ }^{1}$, Carolin R. Löscher ${ }^{4}$, Damian L. Arévalo-Martínez ${ }^{2}$, Elizabeth León-Palmero ${ }^{5}$, Mingshuang Sun ${ }^{2}$, Ruifang C. Xie ${ }^{3}$, Sergey Oleynik ${ }^{1}$, Bess Ward ${ }^{1}$ 
Table S1: Average alpha diversities of total and active archaeal amo $A$ and $n i r S$ communities.

\begin{tabular}{lll}
\hline & nirs & amoA \\
\hline DNA & $3.8 \pm 0.4$ & $3.6 \pm 0.1$ \\
\hline cDNA & $3.4 \pm 0.5$ & $3.2 \pm 0.3$
\end{tabular}


Table S2: Overview of abundant archetypes $(>1 \%)$ that are significantly enriched in respective $\mathrm{O}_{2}$ levels (Lefse analysis). $\mathrm{O}_{2}$ levels were split in 3 categories: anoxic $\left(<1 \mu \mathrm{mol} \mathrm{L}-1 \mathrm{O}_{2}\right.$, Seabird $\mathrm{O}_{2}$ and Winkler titration detection limits), hypoxic $\left(1-10 \mu \mathrm{mol} \mathrm{L}^{-1} \mathrm{O}_{2}\right)$, oxic $\left(>10 \mu \mathrm{mol} \mathrm{L}^{-1} \mathrm{O}_{2}\right)$.

\begin{tabular}{|c|c|c|c|c|c|c|c|c|}
\hline amoA & archetype & anoxic & hypoxic & oxic & nirs & archetype & anoxic hypoxic & oxic \\
\hline \multirow[t]{5}{*}{ DNA } & AOA3 & & & $x$ & DNA & nir4 & & $x$ \\
\hline & AOA7 & $x$ & & & & nir14 & & $x$ \\
\hline & AOA78 & & & $x$ & & nir23 & $x$ & \\
\hline & AOA83 & & & $x$ & & nir46 & $x$ & \\
\hline & & & & & & nir166 & $x$ & \\
\hline \multirow[t]{5}{*}{ cDNA } & AOA3 & & & $x$ & cDNA & nir4 & & $x$ \\
\hline & AOA7 & & $x$ & & & nir14 & & $x$ \\
\hline & AOA83 & & & $x$ & & nir23 & $x$ & \\
\hline & & & & & & nir141 & & $x$ \\
\hline & & & & & & nir166 & $x$ & \\
\hline
\end{tabular}


Table S3: All samples with rates, standard errors, fraction label ( $\mathrm{f}_{\mathrm{N}}$ ), yields, copy numbers $\mathrm{mL}^{-1}$ of $n i r S$ and $a m o A$ genes and transcripts.

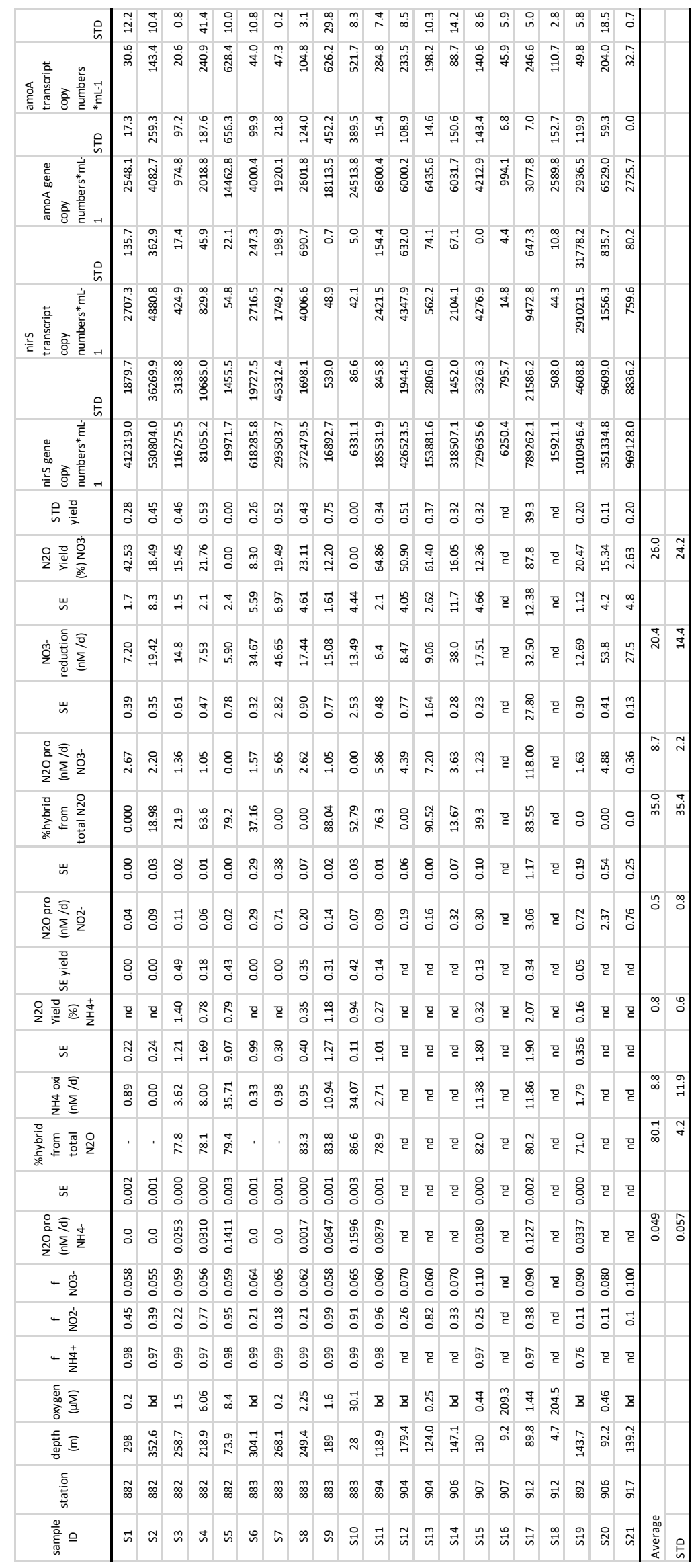




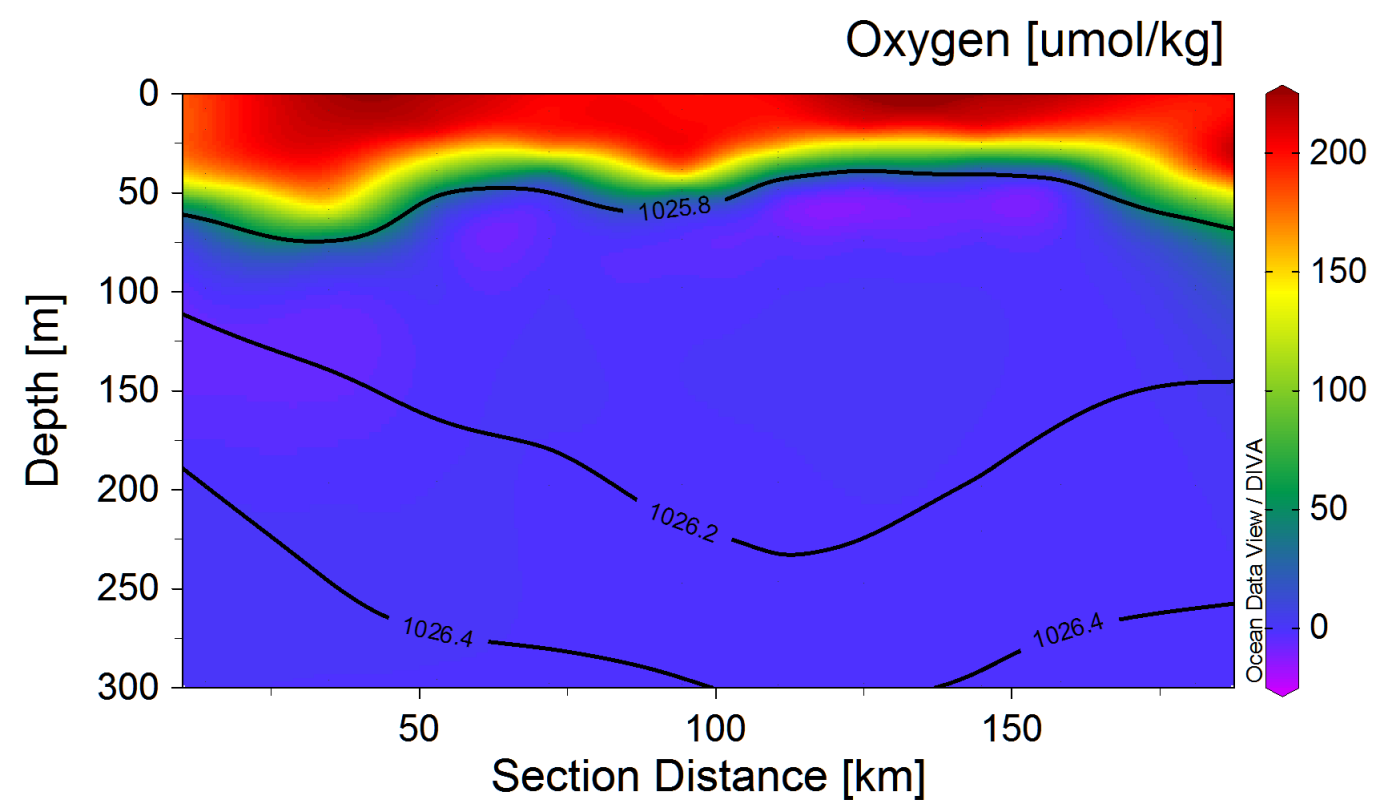

Figure S1: Oxygen and density contours plot from CTD data. 

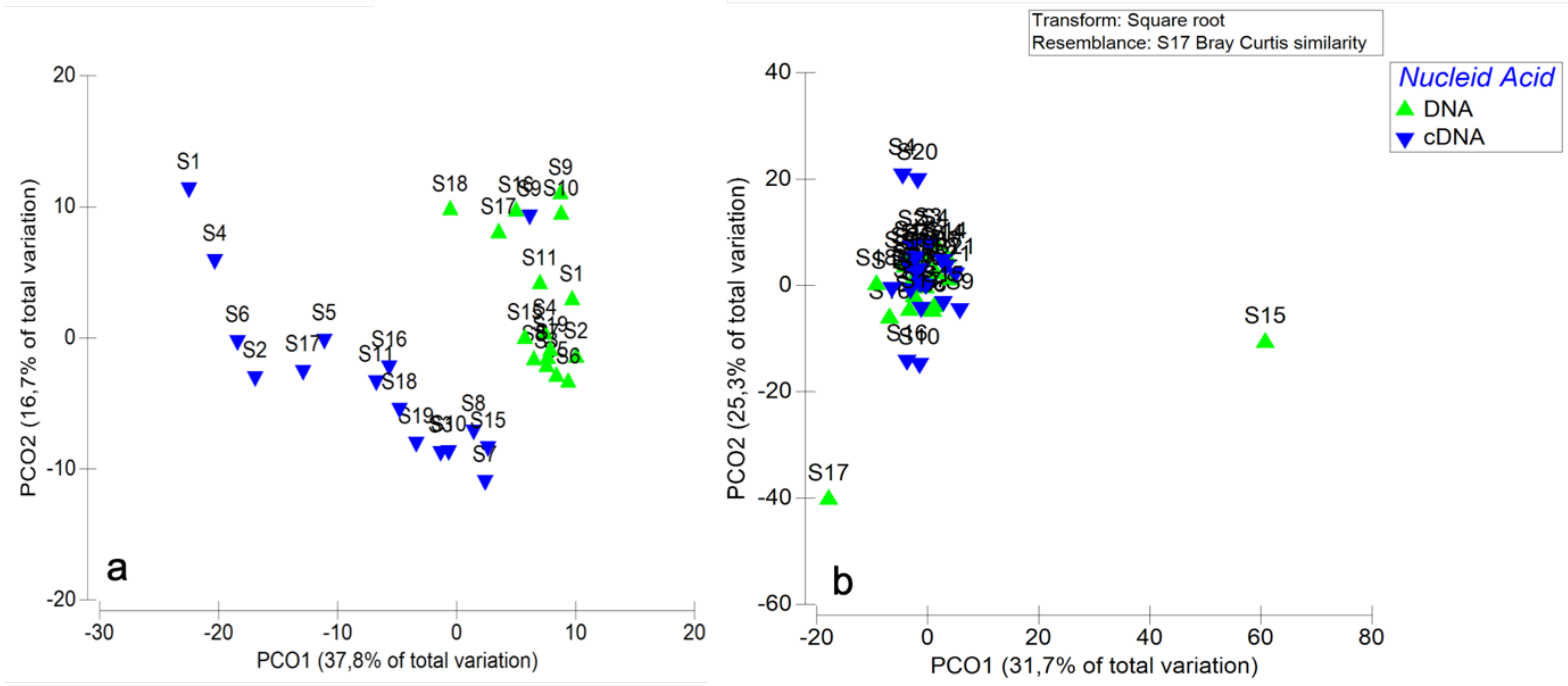

25 Figure S2: Principle component analysis of amoA DNA and cDNA (a) and nirS DNA and cDNA (b). 


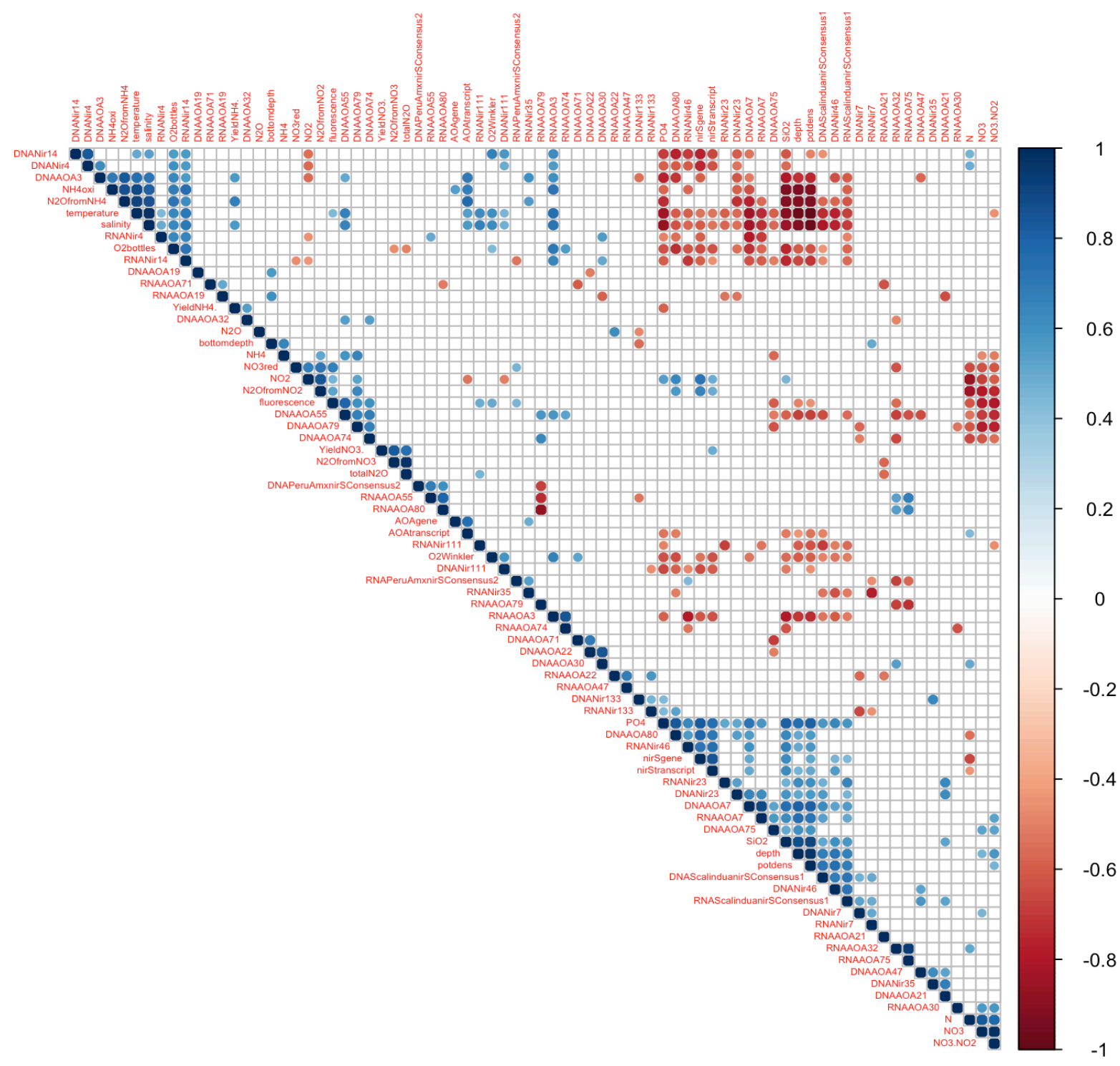

Figure S3: Heat map of significant positive (blue) or negative (red) correlations $(\mathrm{p}<0.05)$ based on a Spearman Rank correlation analysis. 


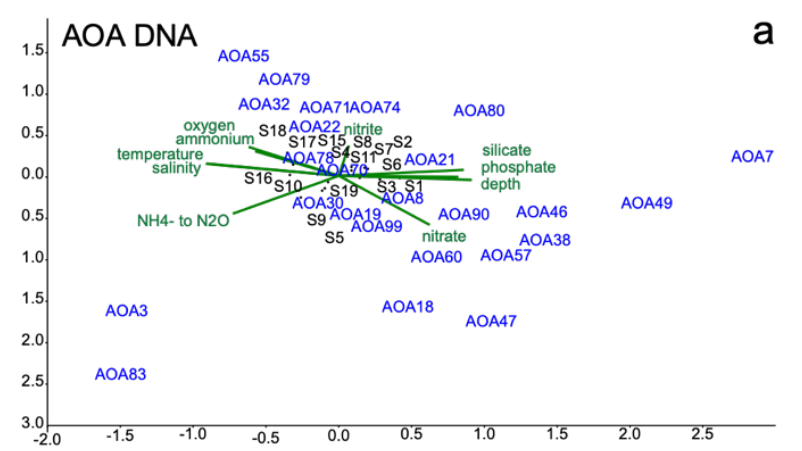

a ${ }^{4} \mathrm{AOA}_{\text {AOA94 }}$

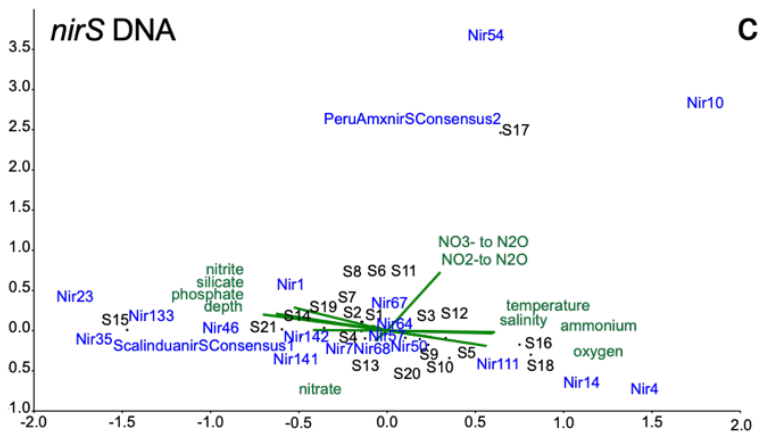

C

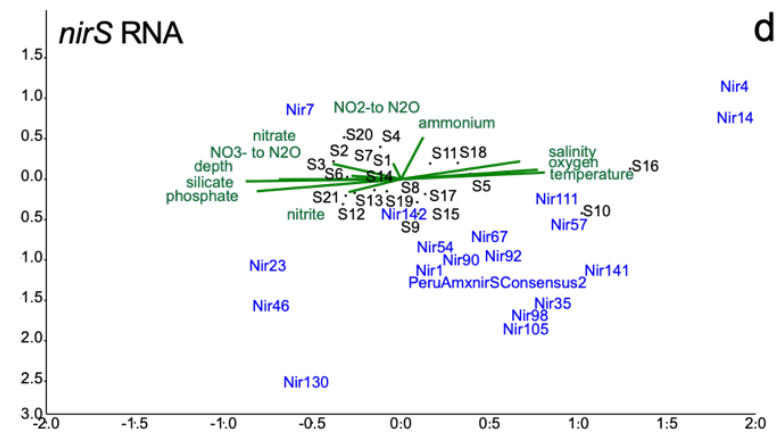

Figure S4: Triplot of Canonical Correspondence Analysis showing the archetype composition as a response to the environmental parameters. Upper panel shows $\operatorname{amoA}(\mathrm{a}, \mathrm{b})$ and lower panel $\operatorname{nir} S$ archetypes (c,d). On the right is the DNA $(a, c)$ and on the left is the cDNA $(b, d)$. 


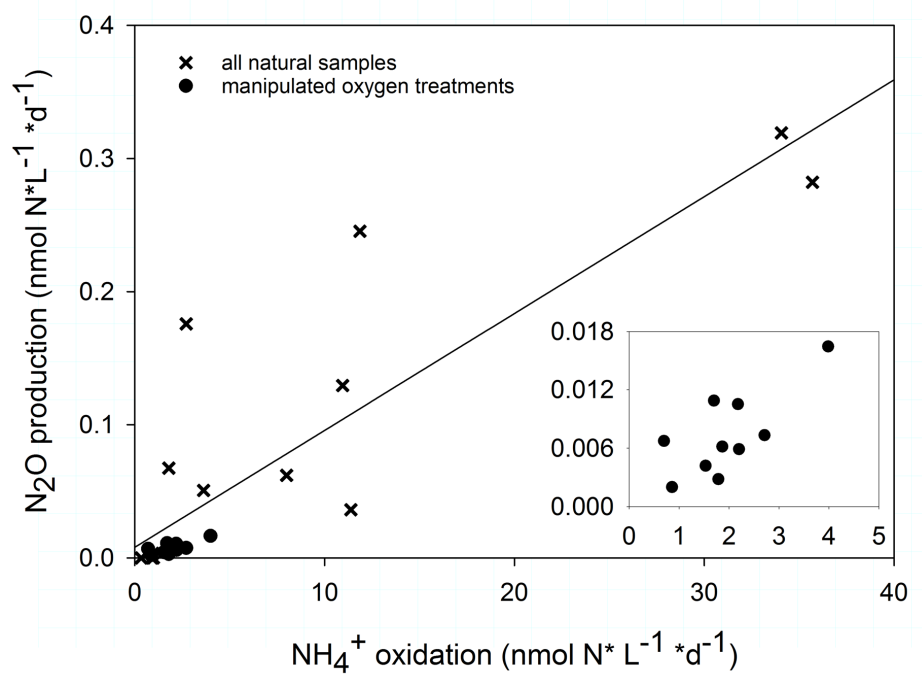

40 Figure S5: Scatter plot of $\mathrm{AO}$ versus $\mathrm{N}_{2} \mathrm{O}$ production from $\mathrm{NH}_{4}{ }^{+}$, zoom up shows manipulated treatments with small AO rates. Linear fit with $y=0.0088 \mathrm{x}+0.0080 \mathrm{R}^{2}=0.75, \mathrm{p}<0.0001$. 


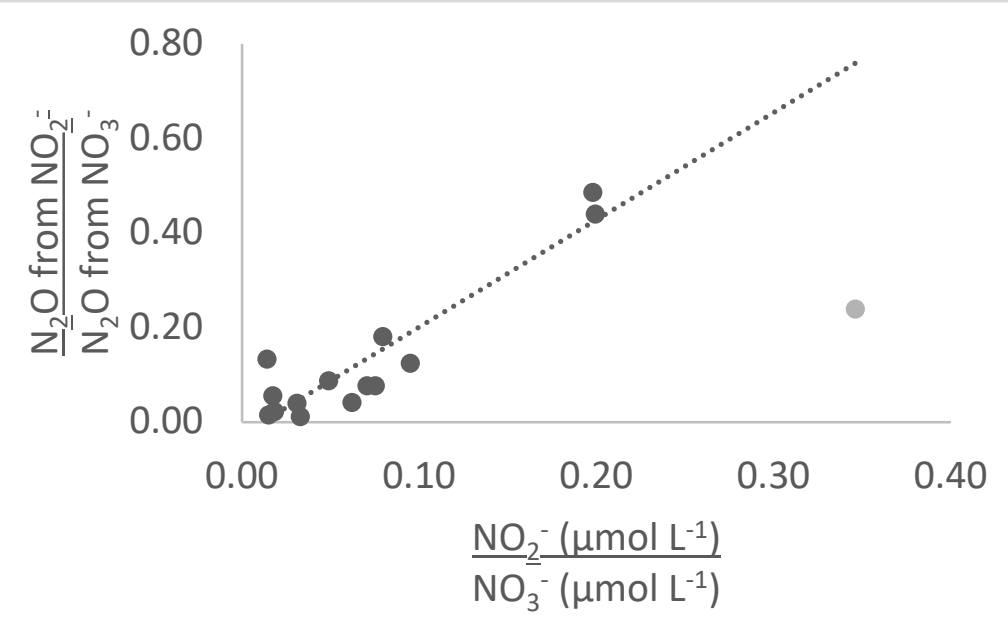

45 Figure S6: Scatter plot of the ratio of $\mathrm{N}_{2} \mathrm{O}$ production rates from $\mathrm{NO}_{2}{ }^{-}$and that from $\mathrm{NO}_{3}{ }^{-}$plotted against ratio of $\mathrm{NO}_{2}{ }^{-}$and $\mathrm{NO}_{3}{ }^{-}$concentrations. Linear fit with $\mathrm{y}=2.267 \mathrm{x}-0.0254 \mathrm{R}^{2}=0.86, \mathrm{p}<0.0001$ 